\title{
CADMIUM CONCENTRATIONS IN FRANCISCANA DOLPHIN (Pontoporia blainvillei) FROM SOUTH BRAZILIAN COAST*
}

\author{
Paulo Renato Dorneles ${ }^{1,2^{* *}}$; José Lailson-Brito ${ }^{1,2}$; Eduardo Resende Secchi ${ }^{3}$; Manuela Bassoi ${ }^{3}$; Catarina Pereira \\ Coutinho Lozinsky ${ }^{2}$; João Paulo Machado Torres ${ }^{l}$ \& Olaf Malm $^{l}$
}

${ }^{1}$ Universidade Federal do Rio de Janeiro, Instituto de Biofísica Carlos Chagas Filho Laboratório de Radioisótopos Eduardo Penna Franca

(Rio de Janeiro, RJ, Brasil)

${ }^{2}$ Universidade do Estado do Rio de Janeiro, Departamento de Oceanografia

Laboratório de Mamíferos Aquáticos

(Rio de Janeiro, RJ, Brasil)

${ }^{3}$ Fundação Universidade do Rio Grande - FURG, Laboratório de Tartarugas e Mamíferos Marinhos Departamento de Oceanografia e Museu Oceanográfico "Prof. Eliézer de Carvalho Rios"

(Rio Grande, RS, Brasil)

**dorneles@biof.ufrj.br

\section{A B S TR A C T}

Franciscana dolphins were used as source of information on the bioavailability of cadmium in the neritic waters off South Brazilian Coast. Liver samples obtained from 44 individuals incidentally captured off Rio Grande do Sul State were analyzed by electrothermal AAS. Cadmium concentrations, age, total weight and length of the analyzed dolphins varied between 39 and 4144 $\mu \mathrm{g} . \mathrm{kg}^{-1}$ (wet weight), one and five years, 17.5 and $49.2 \mathrm{~kg}$, and between 105.3 and $156.8 \mathrm{~cm}$, respectively. Concerning hepatic cadmium concentrations of franciscanas, there was no significant difference between data raised by the present study and information from literature, regarding Rio de Janeiro State. The low cadmium concentrations observed may be attributed to the fact that loliginid squids constitute the main cephalopod prey for franciscanas. This study corroborates investigations on cadmium levels in Brazilian squids and strengthened the hypothesis that cephalopods of Loliginidae Family do not constitute important vectors of the transfer of cadmium to cetaceans.

\section{R ESUMO}

Franciscanas foram utilizadas como fonte de informação sobre a biodisponibilidade de cádmio em águas neríticas da Costa Sul do Brasil. Amostras de fígado, obtidas de 44 indivíduos capturados acidentalmente ao largo da costa do Rio Grande do Sul, foram analisadas através de EAA eletrotérmica. Concentrações de cádmio, idade, peso e comprimento totais dos golfinhos analisados variaram entre 39 e $4144 \mu \mathrm{g} \cdot \mathrm{kg}^{-1}$ (peso úmido), um e cinco anos, 17,5 e 49,2 kg, e entre 105,3 e 156,8 $\mathrm{cm}$, respectivamente. Em relação às concentrações hepáticas de cádmio em franciscanas, não houve diferença significativa entre os dados gerados pelo presente estudo e informação proveniente da literatura, referente ao Estado do Rio de Janeiro. As baixas concentrações de cádmio observadas podem ser atribuídas ao fato de as lulas da Família Loliginidae constituírem a principal presa para franciscanas, dentre os cefalópodes. Este estudo corrobora investigações sobre níveis de cádmio em lulas brasileiras e reforça a hipótese de que cefalópodes loliginídeos não constituem vetores importantes da transferência de cádmio para cetáceos.

Descriptors: Cadmium, Southwest Atlantic Ocean, Brazil, Franciscana, Dolphin, Cetacean. Descritores: Cádmio, Atlântico Sul Ocidental, Brasil, Franciscana, Boto, Cetáceo.

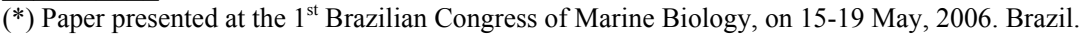




\section{INTRODUCTION}

Many micropollutants are turned bioavailable due to anthropogenic activities or even synthesized by mankind and, in general, aquatic ecosystems constitute the final destiny for these contaminants, which end up accumulating in organisms. Among the pollutants that go through manmade mobilization is cadmium, a heavy metal of great environmental concern.

There is evidence to suggest that cadmium levels in air, water and soils have increased severalfold in many parts of the world as a result of emissions from industrial activities and that the natural biogeochemical cycle of this toxic element has been overwhelmed (Nriagu, 1990). Presently, in Brazil, industrial and urban developments spread along the entire shoreline; however, they are particularly concentrated along South Brazilian Coast. According to a characterization of the Brazilian Littoral (Ekau \& Knoppers, 1999) based on similarities of bathymetrical, hydrographical and biological parameters, the South Brazilian Coast comprises Rio de Janeiro, São Paulo, Paraná, Santa Catarina and Rio Grande do Sul States (Fig.1).

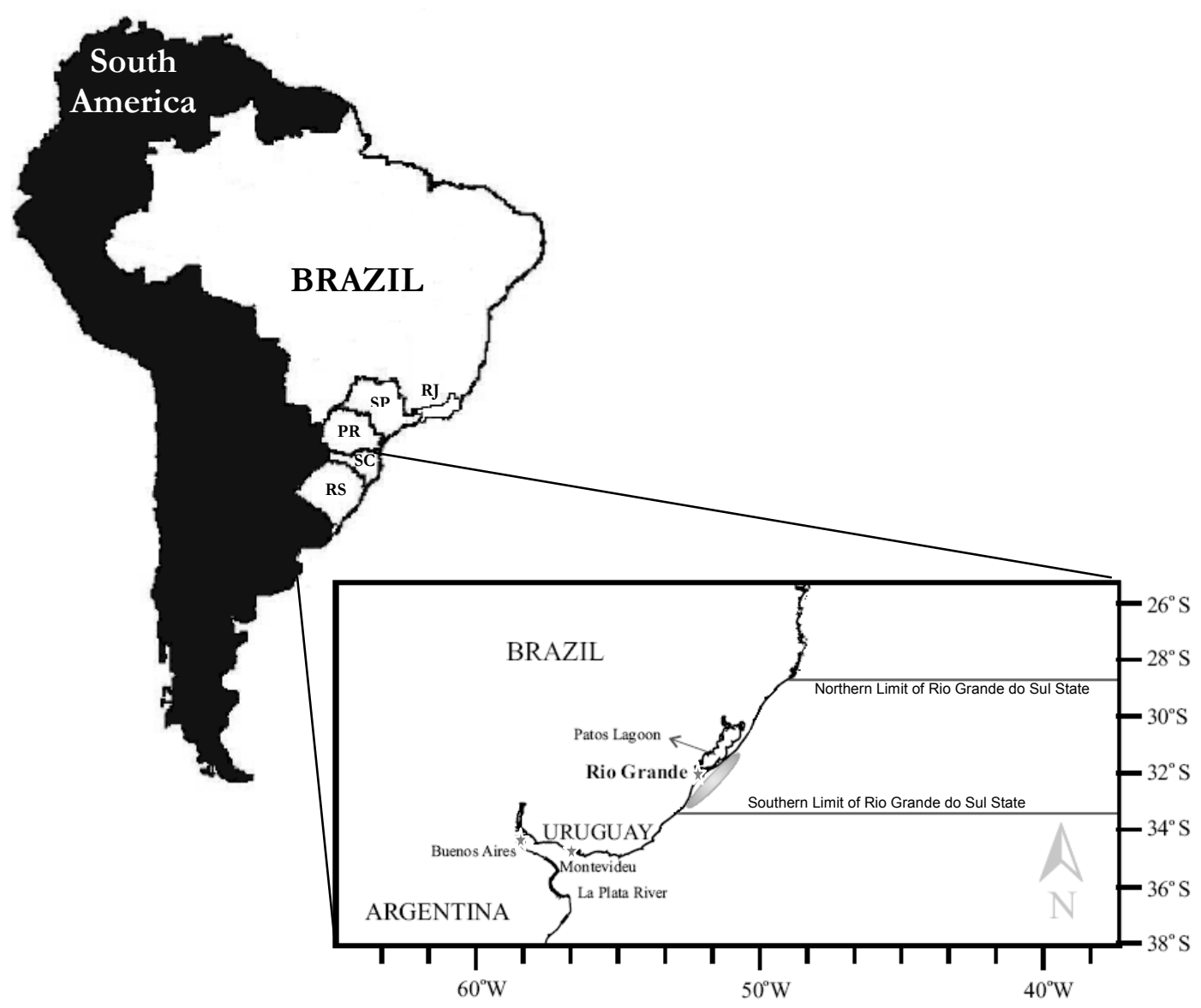

Fig. 1. South America map emphasizing Brazil and the Brazilian states that constitute the South Brazilian Coast, i.e., Rio de Janeiro (RJ), São Paulo (SP), Paraná (PR), Santa Catarina (SC) and Rio Grande do Sul (RS), as well as amplifying the region in which the Rio Grande do Sul State is included, showing the sampling area (gray). The gray stars spot the cities of Rio Grande (RS, Brazil), Montevideo (Uruguay) and Buenos Aires (Argentina). 
Considering the mentioned above, it is of great interest to investigate the possibility of a manmade enrichment of cadmium in neritic waters of the concerned portion of the Brazilian coast. However, probably due to problems on cadmium determination in water, associated with difficulties for logistic representative sampling, this type of research has not yet been accomplished in Brazil.

Since it is often possible to detect pollutant metals in marine organisms when concentrations in water are too low or too variable to be determined with confidence by routine chemical analyses, the use of nektonic organisms to screen the neritic environment in search of cadmium has an obvious attraction.

Carnivorous marine mammals are regarded as valuable indicators of the level of heavy metals accumulated in marine environment, due to their top position in the food web and their long life span (Das et al., 2000; 2003; Reddy et al., 2001).

Therefore, hepatic cadmium levels in franciscana dolphins (Pontoporia blainvillei) were used as source of information about cadmium contamination in neritic waters of South Brazilian Coast.

Franciscana is endemic to the western South Atlantic, ranging from Espírito Santo State $\left(\sim 18^{\circ} \mathrm{S}\right)$, Brazil (Siciliano, 1994$)$ to Chubut Province $\left(\sim 42^{\circ} \mathrm{S}\right)$, Argentina (Crespo et al., 1998), occurring in shallow waters roughly within $55 \mathrm{~km}$ of shore (Pinedo et al., 1989; Secchi \& Ott, 1997).

Based on morphological differences, Pinedo (1991) proposed two different forms of franciscana, one found to the north and the other to the south of Santa Catarina State. Sequence differences in the displacement loop (D-loop) region of the mtDNA between these geographic forms of franciscana were found, suggesting the existence of at least two genetic populations or management stocks (Secchi et al., 1998). Applying the phylogeographic concept of stock (Dizon et al., 1992) using available genotipic, fenotipic, life history and distributional data, Secchi et al. (2003) proposed that franciscana should be splitted into four stocks for management purposes. Each stock inhabits discrete areas named Franciscana Management Areas (FMA): FMA I, including coastal waters of Espírito Santo and Rio de Janeiro; FMA II, covering São Paulo to Santa Catarina States; FMA III, comprising the coastal waters of Rio Grande do Sul and Uruguay; and FMA IV, representing the coastal waters of Argentina. The latter authors emphasized that the arguments presented in their study for the proposed divisions are not immutable and they recommended, for further improvement, studies on contamination load, among other surveys. Therefore, we also investigated the possibility of any difference in hepatic cadmium concentration between franciscanas from Rio Grande do Sul (FMA III), and
Rio de Janeiro (FMA I). Information about levels of the quoted metal in liver of franciscanas incidentally captured off Rio de Janeiro coast is published in Lailson-Brito et al. (2002). Hence, the present study would be able to verify if there is dissimilarity on cadmium exposure for the same dolphin species in both extremes of the concerned area.

\section{Materials And Methods \\ Sampling and Sample Preparation}

Liver samples were obtained from 44 franciscanas incidentally caught in gillnets by the coastal commercial fleet sited in Rio Grande $\left(32^{\circ} 08^{\prime} \mathrm{S}\right.$, $52^{\circ} 05^{\prime} \mathrm{W}$ ), Rio Grande do Sul State, from 1994 to 2000 (Fig. 1). After dissection, samples were stored in individual polyethylene bags and kept frozen $\left(-20^{\circ} \mathrm{C}\right)$ until analysis. Data on age were obtained from a parallel study (Danilewicz et al., 2000), in which the methodology is described in detail. Briefly, specimens have had their age determination based on growth layer groups (GLGs) present in dentine and cementum of the teeth.

\section{Analytical Procedure}

Aliquots of approximately $200 \mathrm{mg}$ of liver were digested with $2 \mathrm{~mL}$ of $65 \% \mathrm{HNO}_{3}$ in a screwcapped vessel, during $24 \mathrm{~h}$. The vessel was then heated to $60^{\circ} \mathrm{C}$ for $120 \mathrm{~min}$ in a water bath. After cooling, the sample was made up to a known volume with high purity deionised water (18.2 $\mathrm{M} \Omega \mathrm{cm}$ ) from a Milli-Q system. Cadmium was determined by electrothermal atomic absorption spectrometry (ET AAS), using an Analytic Jena spectrometer ZEEnit 60 equipped with Zeeman-effect background correction. Palladium nitrate was used as a matrix modifier. Blanks and reference material, dogfish liver (DOLT-2, NRCC), were carried through the procedure in the same way as the samples and our results (in $\mu \mathrm{g} . \mathrm{g}^{-1} \pm$ S.D.) for the determination of cadmium in DOLT-2 $(20.92 \pm 0.04)$ were in good agreement with certified value $(20.8 \pm$ $0.5)$. The detection limit of the method was $4 \mu \mathrm{g} \cdot \mathrm{kg}^{-1}$, wet weight.

\section{RESULTS}

Concerning the analyzed franciscanas from neritic waters of Rio Grande do Sul State, hepatic cadmium concentration ( $\mu \mathrm{g} \cdot \mathrm{kg}^{-1}$, wet weight) varied from 39 to 4144, age varied from 1 to 5 years, weight $(\mathrm{kg})$ varied from 17.5 to 49.2 , and total length $(\mathrm{cm})$ varied from 105.3 to 156.8 (Table 1).

The Spearmann test was used in order to investigate the existence of correlation between cadmium concentration in liver and total length, age 
and weight of the analyzed franciscanas. The test pointed out the presence of a positive correlation for total length $\left(\mathrm{r}_{\text {Spearmann }}=0.41, \quad \mathrm{p}<0.05\right)$ and age $\left(\mathrm{r}_{\text {Spearmann }}=0.63, \mathrm{p}<0.05\right) \quad$ (Fig. 2), as well as the absence of correlation for weight $(\mathrm{p}>0.05)$. There was no significant difference $(p>0.05)$ in cadmium concentrations between sexes (Mann-Whitney U test, $\mathrm{p}$ $>0.05)$.

Table 1. Range, mean, median and number $(n)$ of samples considered, regarding hepatic cadmium concentration ( $\mu$ g.kg ${ }^{-1}$, wet weight), age (years), weight $(\mathrm{kg})$ and total length $(\mathrm{cm})$ of the analyzed franciscanas from neritic waters of Rio Grande do Sul State.

\begin{tabular}{ccccc}
\hline \hline Parameters & Range & Mean & Median & $\boldsymbol{n}$ \\
\hline [Cd] $\left(\boldsymbol{\mu g . \mathbf { k g } ^ { - 1 } )}\right.$ & $39-4144$ & 580.3 & 358.5 & 44 \\
& & & & \\
Age (years) & $1.0-5.0$ & 2.7 & 3 & 11 \\
& & & & \\
Weight (kg) & $17.5-49.2$ & 29.3 & 29.4 & 31 \\
& & & & \\
Length (cm) & $105.3-156.8$ & 130.1 & 131.4 & 33 \\
\hline
\end{tabular}

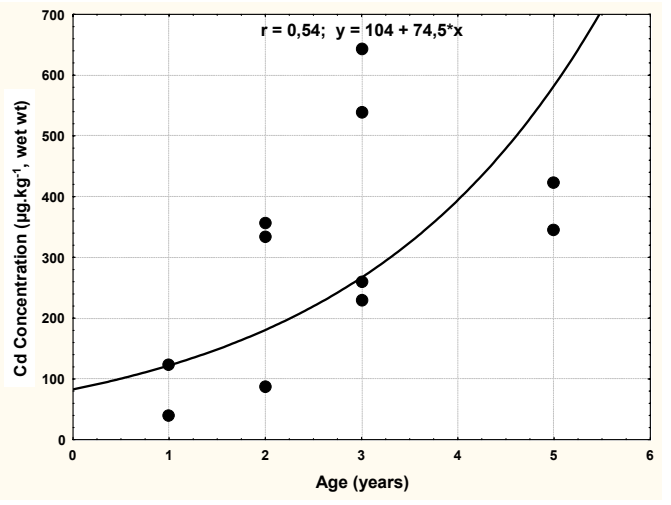

Fig. 2. Hepatic Cd concentrations ( $\mu \mathrm{g} \cdot \mathrm{kg}^{-1}$ wet wt) versus age (years) in franciscanas.

\section{Discussion}

The Mann-Whitney $U$ test showed the absence of significant difference between hepatic cadmium concentrations of franciscanas from Rio Grande do Sul Coast, determined in the present study, and cadmium levels reported by Lailson-Brito et al. (2002) for the same organ and dolphin species, concerning individuals from Rio de Janeiro Coast $(\mathrm{p}>$ 0.05 ). The quoted statistical test was used taking into consideration the age of individuals from both stocks of franciscana. Therefore, since the age of the dolphins from the present study varied from 1 to 5 years, the test was carried out using only individuals whose age fitted within the same range, among the quoted franciscanas reported by Lailson-Brito et al. (2002). The result of the test mentioned clearly demonstrates that the two franciscana stocks considered are equally exposed to cadmium in both extremes of the South Brazilian Coast.

The concerned area presents some noteworthy spots related to heavy metal pollution. The Paraiba do Sul River, for instance, flows through the State of Rio de Janeiro in a west-east direction towards its outfall into the Atlantic Ocean. The river, with a water flux of about $250 \mathrm{~m}^{3} \cdot \mathrm{s}^{-1}$ at its upper reaches, crosses one of the most industrialized areas of the state and receives organic and inorganic effluents of different kinds, including discharges from metallurgical, chemical and pharmaceutical plants, slaughterhouses, as well as sewage from a densely populated area (Pfeiffer et al., 1986).

Besides the anthropogenic input of cadmium, there is a possibility of a natural enrichment of this metal in the neritic environment of South Brazilian Coast, since cadmium is enriched in surface waters of upwelling areas (Martin \& Broenkow, 1975) and the area considered here is strongly influenced by this phenomenon, especially the region between Cabo Frio $\left(23^{\circ} \mathrm{S}\right)$ and São Sebastião $\left(24^{\circ} \mathrm{S}\right)$ over a great extent of the continental shelf (Borzone $e t$ al., 1999).

The main ways of cadmium transport from continent to coastal regions are fluvial influx and atmospheric precipitation (Yeats \& Bewers, 1987). Regarding the latter via, there is another important area to be considered on the southern extreme of the concerned area, since Brazilian coalfields are located in the country's southern region, with the States of Rio Grande do Sul and Santa Catarina accounting for 99\% of the country's coal production (Bizarro-César, 2000; Silva, 1993). This is an important aspect to be considered when environmental pollution by cadmium is concerned, as the coal mining activity is characterized by the generation of large amounts of by-products including the quoted metal (Nriagu \& Pacyna, 1988). In addition, a recent study has shown the process of environmental contamination by cadmium arising from emissions of phosphate fertilizer factories located on a peninsula in the Patos Lagoon estuary, in southern Brazil (Mirlean \& Roisenberg, 2006).

Despite all the aspects that could contribute to an enrichment of cadmium in the neritic environment of South Brazilian Coast, the hepatic cadmium concentrations of franciscanas cannot be considered as high for dolphins, specially when comparing them with concentrations from other cetacean species from Brazil. In Fraser's dolphins 
(Lagenodelphis hosei) stranded on Rio de Janeiro State, it was observed that hepatic cadmium concentrations ( $\mu \mathrm{g} \cdot \mathrm{kg}^{-1}$ wet weight) reached 42200 in this oceanic species (Lailson-Brito et al., 2000). Lailson-Brito (1994) also reported high levels in other oceanic dolphins from Brazil since the quoted study mentioned the hepatic cadmium concentrations of 10110 and 13000 (both $\mu \mathrm{g} \cdot \mathrm{kg}^{-1}$ wet weight) in a common dolphin (Delphinus delphis) and in a clymene dolphin (Stenella clymene), respectively.

The main route of cadmium contamination for marine mammals seems to be via feeding (Ray \& McLeese, 1987; Johnston et al., 1996; Law, 1996; Bowles, 1999; Gray, 2002; Das et al., 2003) and cadmium levels are higher in cetacean species that feed primarily on squid, compared with species that feed more on fish (Johnston et al., 1996; Law, 1996; Reijnders, 1996; O'Hara \& O'Shea, 2001; Das et al., 2003).

An important study on feeding ecology of franciscana dolphins revealed that, in quantitative terms, cephalopods are of greater importance on the diet of the species than fish (Di Beneditto, 2000). However, notwithstanding being primarily a squideating odontocete, in two researches that analyzed stomach contents of franciscanas, from Rio de Janeiro (Di Beneditto, 2000) and Rio Grande do Sul (Santos \& Haimovici, 2001) States, squids of the Loliginidae Family were by far the most important prey among cephalopod species. This information explains the low cadmium levels observed, since a recent study on concentrations of the quoted metal in Brazilian cephalopods has shown that squids of the Ommastrephidae Family exhibited far higher cadmium concentrations than loliginids (Dorneles et al., 2007).

The occurrence of lower cadmium concentrations in lolignid cephalopods than in ommastrephid squids may be related to differences in their digestive physiology. The digestive gland cells of loliginid squids present some differences from those of other cephalopods. They do not have some structures called "boules", considered as heterolysosomes and heterophagosomes, and the lack of these structures in these cells might mean that the processes of particle capture and intracellular digestion do not occur widely in their digestive glands (Boucher-Rodoni \& BoucaudCamou, 1987). Such processes can be decisive for the remarkable cadmium absorption efficiency of 53\% observed in the cephalopod Sepia officinalis (Bustamante et al., 2002), over 10 times higher than the 5\% verified in mammals (Elinder \& Järup, 1996). Therefore, given the importance of the absorption efficiency of a certain micropollutant to its bioaccumulation, it is plausible to believe that the other cephalopods may present a higher cadmium bioaccumulation capacity than those of the Loliginidae Family.

Nevertheless, environmental aspects cannot be dismissed when searching for explanation for the lower cadmium concentrations observed in loliginids than in other squids, since there is a remarkable difference in habitat between both groups. Squids of the Loliginidae Family are inhabitants of coastal and continental shelf areas, while squids other than loliginids, like the Ommastrephidae Family mentioned, frequently occupy the open oceans environment (Roper et al., 1984).

Considering that longer food chains may favour the occurrence of higher cadmium levels on nektonic predators (Dietz et al., 1998) and that oligotrophic oceanic environments are characterized by this feature, it can be concluded that the difference between cadmium concentrations observed in loliginids and in other squids may also be related to oceanic or coastal habitats.

In fact, the situation observed in Brazil corroborates data from literature, since cadmium levels observed in other cephalopods have been higher than those verified in loliginids. Lahaye et al. (2005) analyzed cephalopods from Bay of Biscay and a comparison between cephalopod families revealed decreasing levels of cadmium with cranchids > histioteuthids $>$ ommastrephids $>$ loliginids. Bustamante et al. (1998) verified higher cadmium concentrations in ommastrephids than in loliginids in French, Irish and Faroese waters, demonstrating a situation that had already been characterized also in North Pacific, since Ommastrephes bartrami presented higher cadmium concentration than Loligo opalescens in that part of the globe (Martin \& Flegal, 1975).

Therefore, the quoted difference in cadmium concentration among cephalopod families may be a result of either environmental or physiological aspects, or, most probably, a consequence of both.

Some recent investigations have already demonstrated the possibility of using cadmium as an auxiliary tool for understanding feeding ecology of marine mammals and, hence, allowing the discrimination of distinct populations or management stocks of the same species by differences in prey availability (Bustamante et al., 2004; Lahaye et al., 2005).

As mentioned, hepatic cadmium concentrations in franciscanas from FMA I and III did not differ significantly. However, analyzing kidney samples of 2 franciscanas from Argentinean waters (i.e. FMA IV), Marcovecchio et al. (1990) found an average cadmium concentration of $9900 \mu \mathrm{g} \cdot \mathrm{kg}^{-1}$ (wet wt.). Concentrations observed by the authors in Argentina were higher than those found by Lailson- 
Brito et al. (2002) in individuals of the same species caught off Rio de Janeiro coast, since the highest renal cadmium concentration verified among 17 franciscanas analyzed in the latter study was 1200 $\mu \mathrm{g} . \mathrm{kg}^{-1}$ ww (Lailson-Brito et al., 2002).

Although there is an obvious need for amplification concerning the number of analyzed franciscanas from Argentinean waters, the data produced by Marcovecchio et al. (1990) corroborate information both on the feeding ecology and on parasite loads of the species. Regarding the former field of knowledge mentioned, diet was more similar among individuals inhabiting adjacent areas of Rio Grande do Sul and Uruguay (see Pinedo, 1982; Pinedo et al., 1989; Ott, 1994; Bassoi, 1997; Danilewicz et al., 2002) than between these two areas and Argentina (Rodríguez et al., 2002). With reference to parasites, Andrade et al. (2000) stated that the distribution pattern of gastrointestinal helminths in franciscana was similar among individuals sampled in Rio Grande do Sul and Uruguay, while Aznar et al. (1995) comparing the helminthofauna of franciscana between samples from Uruguay and Argentina observed differences in dominance and infection levels by the acanthocephalan worm Polymorphus cetaceum, the nematode Anisakis simplex, as well as by the trematode Hadwenius pontoporiae.

\section{Conclusions}

The comparison between cadmium concentrations of franciscana dolphins from neritic waters of Rio de Janeiro and Rio Grande do Sul States shows that the species is equally exposed to cadmium in both extremes of South Brazilian Coast.

The low hepatic cadmium concentrations of franciscanas recorded in the present study corroborate investigations on cadmium levels in Brazilian squids and strengthened the hypothesis that cephalopods of the Loliginidae Family do not constitute important vectors of the transfer of the quoted metal to cetaceans in the Brazilian coast. In fact, with reference to the franciscana dolphin, there is no important vector of the transfer of cadmium to the species.

Considering the essential importance of the establishment of management procedures for conservation of franciscana dolphin (Pontoporia blainvillei), as well as the usefulness of the knowledge on cadmium concentrations as an auxiliary tool for discriminating distinct populations or management stocks of dolphin species, determination of the quoted metal in tissues of franciscanas from throughout its distribution area is strongly recommended.

\section{AcKNOWLEDGMENTS}

The authors give thanks to Radioisotopes Laboratory (UFRJ), Aquatic Mammals Laboratory (UERJ) and Marine Mammals Laboratory (Oceanographic Museum, FURG) teams. The manuscript was improved thanks to constructive criticism from two anonymous reviewers. This work was supported by the Ministry of Education of Brazil - CAPES (fellowship to P. R. Dorneles) and by the Brazilian Research Council - CNPq.

\section{REFERENCES}

ANDRADE, A. L. V.; PINEDO, M. C.; PEREIRA, J. J. As franciscanas do Sul do Brasil, Uruguai e Argentina constituem distintos estoques? In: UNEP/CMS ed. Report of the Third Workshop for Coordinated Research and Conservation of the Franciscana Dolphin (Pontoporia blainvillei) in the Southwestern Atlantic. Bonn: UNEP/CMS, 2000. p. 104-105. 2000.

AZNAR, F. J. et al. Helminths as biological tags for franciscana Pontoporia blainvillei (Cetacea, Pontoporiidae) in Argentinean and Uruguayan waters. Mammalia, v. 59, n. 3, p. 427-35, 1995.

BIZARRO-CÉSAR, S. Carvão mineral. In: SUMÁRIO MINERAL 1999. Brasília, DF: Ministério de Minas e Energia., Departamento Nacional de Produção Mineral, 2000. p. 30-31.

BORZONE, C. A.; PEZZUTO, P. R.; MARONE, E.; Oceanographic characteristics of a multi-specific fishing ground of the Central South Brazil Bight. Mar. Ecol., v. 20, n. 2, p. 131-146, 1999.

BOUCHER-RODONI, R.; BOUCAUD-CAMOU, E. Fine structure and absorption of ferritin in the digestive organs of Loligo vulgaris and L. forbesi (Cephalopoda, Teuthoidea). J. Morphology, v. 193, p. 173-184, 1987.

BOWLES, D. An overview of the concentrations and effects of metals in cetaceans species. J. Cetacean Res. Manage., v. 1, p. 125-148, 1999. Spec. Iss.

BUSTAMANTE, P. et al. Cephalopods as a vector for the transfer of cadmium to top marine predators in the northeast Atlantic Ocean. Sci. Total Environ., v. 220, p. 7180, 1998.

BUSTAMANTE, P. et al. Biokinetics of zinc and cadmium accumulation and depuration at different stages in the life cycle of the cuttlefish Sepia officinalis. Mar. Ecol. Progr. Ser., v. 231, p. 167-177, 2002.

BUSTAMANTE, P. et al. Trace element bioaccumulation in grey seals Halichoerus grypus from the Faroe Islands. Mar. Ecol. Progr. Ser., v. 267, p. 291-301, 2004.

CRESPO, E. A.; HARRIS, G.; GONZÁLEZ, R. Group size and distributional range of the franciscana, Pontoporia blainvillei. Mar. Mammal Sci., v. 14, n. 4, p. 845-9, 1998.

DANILEWICZ, D. et al. Analysis of the age at sexual maturity and reproductive rates of franciscana (Pontoporia blainvillei ) from Rio Grande do Sul, southern Brazil. Comun. Mus. Ciênc. Tecnol. PUCRS, v. 13, p. 89-98, 2000. 
DANILEWICZ, D. et al. Report of the Working Group on Biology and Ecology. Latin Am. J. Aquatic Mammals, v. 1, n. 1, p. 25-42, 2002

DAS, K. et al. Tuna and dolphin associations in the NorthEast Atlantic: evidence of different ecological niches from stable isotope and heavy metal measurements. Mar. Pollut. Bull., v. 40, p. 102-109, 2000.

DAS, K. et al. Heavy metals in marine mammals, In: VOS, J.G. et al. (Ed.). Toxicology of marine mammals. London: Taylor and Francis, 2003. p. 135-167.

DIETZ, R.; PACYNA, J.; THOMAS, J. D. Heavy metals. AMAP Assessment Report-Arctic Pollution Issues. Oslo: Arctic Monitoring Assessment Programme, 1998. p. 373524.

DIZON, A. E. et al. Rethinking the stock concept: a phylogeographic approach. Cons. Biol., v. 6, p. 24-36, 1992.

DORNELES, P. R. et al. Cephalopods and cetaceans as indicators of offshore bioavailability of cadmium off Central South Brazil Bight. Environ. Pollut., v. 148, p. 352-359, 2007.

EKAU, W.; KNOPPERS, B. A. An introduction to the pelagic system of the East and Northeast Brazilian shelf Arch. Fish. Mar. Res., v.47, p. 113-132, 1999.

ELINDER, C. G.; JÄRUP, L. Cadmium exposure and health risks: recent findings. Ambio, v. 25, n. 5, p. 370-373, 1996

GRAY, J. S. Biomagnification in marine Systems: the perspective of an ecologist. Mar. Pollut. Bull., v. 45, p. 46-52, 2002

JOHNSTON, P. A.; STRINGER, R. L.; SANTILLO, D Cetaceans and environmental pollution: the global concerns. In: SIMMONDS, M. P.; HUTCHINSON, J. D. (Ed.) The conservation of whales and dolphins. Chichester: John Wiley and Sons, 1996. p. 219-261.

LAHAYE, V. et al. Long-term dietary segregation of common dolphins Delphinus delphis in the Bay of Biscay, determined using cadmium as an ecological tracer. Mar. Ecol. Progr. Ser., v. 305, p. 275-285, 2005.

LAILSON-BRITO JR., J. et al. Estudo ecotoxicológico das concentrações de cádmio em tecidos de golfinhos (CETACEA, DELPHINIDAE) de hábitos costeiros e oceânicos, de água do Estado do Rio de Janeiro. In: ESPÍNDOLA, E. L. G. et al. (Ed.). Ecotoxicologia: perspectivas para o século XXI. São Carlos, SP: RIMA 2000. p. 183-197.

LAILSON-BRITO JR., J. et al. Trace metal concentrations in liver and kidney of franciscana, Pontoporia blainvillei, of the North coast of the Rio de Janeiro State, Brazil. LAJAM, v. 1, n. 1, p. 107-114, 2002.

LAW, R. J. Metals in marine mammals. In: BEYER, W. N.; HEINZ, G. H.; REDMON-NORWOOD, A. W. (Ed.) Environmental contaminants in wildlife: interpreting tissues concentrations. Boca Raton, FLA: CRC Press, 1996. p. 357-376.

MARCOVECCHIO, J. E. et al. Tissue distribution of heavy metals in small cetaceans from the Southwestern Atlantic Ocean. Mar. Pollut. Bull., v. 21, p. 299-304, 1990.

MARTIN, J. H.; BROENKOW, W.W. Cadmium in plankton: elevated concentrations off Baja California. Science, v. 190, p. 884-885, 1975
MARTIN, J. H.; FLEGAL, A. R. High copper concentrations in squid livers in association with elevated levels of silver, cadmium and zinc. Mar. Biol., v. 30, p. 51-55, 1975.

MIRLEAN, N.; ROISENBERG, A. The effect of emissions of fertilizer production on the environment contamination by cadmium and arsenic in southern Brazil. Environ. Pollut., v. 143, n. 2, p. 335-340, 2006.

NRIAGU, J. O. Food contamination with cadmium in the environment. In: NRIAGU, J. O.; SIMMONS, J. O. (Ed.). Food contamination from environmental sources. New York: John Wiley and Sons, 1990. p. 5984.

NRIAGU, J. O.; PACYNA, J. M. Quantitative assessment of worldwide contamination of air, water and soils by trace metals. Nature (London), v. 333, p. 134-139, 1988.

O'HARA, T. M.; O'SHEA, T. J. Toxicology. In: DIERAUF, L. A.; GULLAND, M. D. (Ed.). Handbook of marine mammal medicine. Boca Raton, FLA: CRC Press, 2001. p. $471-520$

PFEIFFER, W. C. et al. Heavy metal pollution in the Paraiba do Sul River, Brazil. Sci. total Environ., v. 58, p. 7379, 1986.

PINEDO, M. C.; PRADERI, R.; BROWNELL, R. L. Review of the biology and status of the franciscana, Pontoporia blainvillei. In: PERRIN, W. F. et al. (Ed.). Biology and conservation of the River Dolphins. Occas. Pap. UUCN. SSSC3, IUCN, Gland, Switzerland. p. 46-51. 1989

RAY, S.; MCLEESE, D. W. Biological cycling of cadmium in marine environment. In: NRIAGU. J. O.; SPRAGUE, J. B. (Ed.). Cadmium in the aquatic environment. New York: John Wiley and Sons, 1987. p. 199-229.

REDDY, M. L.; DIERAUF, L. A.; GULLAND, F. M. D. Marine mammals as sentinels of the ocean health. In: DIERAUF, A. L.; GULLAND, M. D. (Ed.). Handbook of marine mammal medicine. Boca Raton, FLA: CRC Press, 2001. p.3-13.

REIJNDERS, P. J. H. Organohalogen and heavy metal contamination in cetaceans: observed effects, potential impact and future prospects. In: SIMMONDS, M. P.; HUTCHINSON, J. D. (Ed.). The conservation of whales and dolphins. Chichester: John Wiley and Sons, 1996. p. 205-217.

RODRÍGUEZ, D.; RIVERO, L.; BASTIDA, R. Feeding ecology of the franciscana (Pontoporia blainvillei) in marine and estuarine waters of Argentina. LAJAM v. 1, n. 1, p. 77-94, 2002.

ROPER, C. F. E.; SWEENEY, M. J.; NAUEN, C. E. Cephalopods of the world. FAO Species Catalogue. v. 3. FAO Fish. Synop., v. 125, n. 3, 227 p, 1984.

SANTOS, R. A.; HAIMOVICI, M. Cephalopods in the diet of marine mammals stranded or incidentally caught along southeastern and southern Brazil $\left(21-34^{\circ} \mathrm{S}\right)$. Fish. Res., v. 52, p. 99-112, 2001.

SECCHI, E. R.; OTT, P. H. The depth factor determining the distribution and abundance of franciscana, Pontoporia blainvillei, as demonstrated by a CPUE index approach. Taller para la Coordinación de la Investigación y la Conservación de la Franciscana en el Atlántico Sudoccidental, 3. 26-28 November 1997. Buenos Aires, Argentina. Paper DT 118. 1997 
SECCHI, E. R. et al. Population differentiation in the franciscana (Pontoporia blainvillei) from two geographic locations in Brazil as determined from mitochondrial DNA control region sequences. Can. J. Zool., v. 76, n. 9, p. 1622-1627, 1998.

SECCHI, E. R.; DANILEWICZ, D.; OTT, P. H. Applying the phylogeographic concept to identify franciscana dolphin stocks: implications to meet managemen objectives. J. Cetacean Res. Manage., v. 5, n. 1, p. 6168, 2003.

SICILIANO, S. Review of small cetaceans and fishery interactions in coastal waters of Brazil. Rep. int. Whal. Commn, v. 15, p. 241-50, 1994. Special issue.

SILVA, Z. C. C. da. Candiota coalfield - a world-class Brazilian coal deposit. Int. J. Coal Geol., v. 23, p. $103-$ 116,1993

YEATS, P. A.; BEWERS, J. M. Evidence for anthropogenic modification of global transport of cadmium, In: NRIAGU, J. O.; SPRAGUE, J. B. (Ed.). Cadmium in the aquatic environment. New York: John Wiley and Sons, 1987. p. 19-34.

\section{Sources of Unpublhished Material}

BASSOI, M. Avaliação da dieta de toninhas, Pontoporia blainvillei (Gervais; D'Orbigny, 1844), capturadas acidentalmente na pesca costeira de emalhe, no sul do Rio Grande do Sul. 1997. 68 f. Trabalho de conclusão de curso (bacharelado em oceanologia) - Fundação Universidade do Rio Grande, Rio Grande, 1997.
Di BENEDITTO, A. P. M. Ecologia alimentar de Pontoporia blainvillei e Sotalia fluviatilis (Cetacea) na costa norte do estado do Rio de Janeiro, Brasil. 2000. Tese (Doutorado em Biociências e Biotecnologia) Universidade Estadual do Norte Fluminense, Campos dos Goytacazes, RJ.

LAILSON-BRITO JR., J. Determinação das concentrações de metais-traço ( $\mathrm{Fe}, \mathrm{Cu}, \mathrm{Zn}, \mathrm{Mn}, \mathrm{Cd}, \mathrm{Cr}$ e $\mathrm{Pb}$ ) em tecidos de cetáceos da costa do Brasil. Bachelor Monography. Departamento de Oceanografia, UERJ. 62 p. 1994.

OTT, P. H. Estudo da ecologia alimentar de Pontoporia blainvillei (Gervais; D'Orbigny 1844) (Cetacea, Pontoporiidae) no litoral Norte do Rio Grande do Sul, Sul do Brasil. 1994. 69 f. Dissertação (Mestrado) Universidade Federal do Rio Grande do Sul, Porto Alegre.

PINEDO, M. C. Análise dos conteúdos estomacais de Pontoporia blainvillei (Gervais; D'Orbigny, 1844) e Tursiops gephyreus (Lahille, 1908) (Cetacea, Platanistidae e Delphinidae) na zona estuarial e costeira de Rio Grande, RS, Brasil. 1982. $95 \mathrm{f}$. Dissertação (Mestrado em Oceanografia Biológica) Fundação Universidade do Rio Grande, Rio Grande.

PINEDO, M. C. Development and variation of the franciscana, Pontoporia blainvillei. 1991. $406 \mathrm{f}$. Thesis (Ph. D.) - University of California, Santa Cruz, USA.

(Manuscript received 07 June 2006; revised 23 October 2006; accepted 23 March 2007) 